\title{
Ausencia, resto, objeto: una propuesta de lectura de la fotografía argentina post-dictadura
}

Absence, remnant, object: a reading of post-dictatorship argentine photography

\author{
EDOARDO BALLETTA \\ UNIVERSITÁ DI BOLOGNA · edoardo.balletta@unibo.it
}

Doctor en literaturas hispanoamericanas por la Universitá di Bologna y actualmente trabaja como investigador y docente de la misma universidad. Ha investigado sobre poesía del siglo XX (especialmente las vanguardias y el neobarroco en el área rioplatense) y sobre las representaciones literarias de la identidad nacional en la novela decimonónica y en el ensayo del México postrevolucionario. Desde hace algunos años se dedica a la relación entre artefactos culturales, política y memoria en la Argentina a partir de los '70.

Resumen: La historia de los movimientos para los derechos humanos en la Argentina tiene una relación muy estrecha con la fotografía. Desde las primeras marchas de las Madres en la plaza de Mayo, la fotografía ha tenido una importancia capital entre las formas de comunicación del movimiento de los DDHH en la Argentina, tanto que las fotos-carnet de los desaparecidos pueden considerarse con razón un "emblema político" (Richard, 2000: 31) y un "referente icónico" (Da Silva Catela, 2009: 337) de la misma lucha por la verdad y la justicia en el país rioplatense. El presente artículo propone una lectura general de la fotografía argentina de la post-dictadura (RES, F. Gutiérrez, M. Brodsky, J. Pantoja, I. Ulanovsky, L. Quieto, G. Bettini, G. Germano) empezando por la hipótesis que dicho corpus iconográfico se alimenta de un archivo (el conjunto de imágenes documentales y familiares) y se expresa a partir de tres paradigmas (objeto, resto, ausencia).

Palabras clave: Argentina, post-dictadura, fotografía, testimonio.

\begin{abstract}
The history of movements for human rights in Argentina has a very close relationship with the photography. Since the first marches of the Mothers of Plaza de Mayo, photography has been of fundamental importance among the forms of communication of Human Rights argentine groups and desaparecidos ID Photo-card can be rightly considered a "political emblem "(Richard, 2000: 31) of the struggle for truth and justice in the River Plate country. This article proposes a general reading of post-dictatorship argentine photography (RES, F. Gutierrez, M. Brodsky, J. Pantoja, I. Ulanovsky, L. Quieto, G. Bettini, G. Germano) starting with the hypothesis that this iconographic corpus is fed by an archive of images from the past (family photos and other kinds of materials) and expressed through three paradigms of representation (object, remnant, absence).
\end{abstract}

Key words: Argentina, post-dictatorship, photography, witness. 
Edoardo Balleta. Ausencia, resto, objeto...

¿No hay nadie?, pregunta la mujer del Paraguay.

Respuesta: No hay cadáveres.

N. Perlongher

\section{Introducción}

La historia de los movimientos para los derechos humanos en la Argentina tiene una relación muy estrecha, podríamos afirmar fundante, con la fotografía. Desde las primeras marchas de las Madres en la plaza de Mayo, la fotografía ha tenido una importancia capital entre las formas de comunicación del movimiento de los DDHH en la Argentina, tanto que las fotos-carnet de los desaparecidos pueden considerarse con razón un "emblema político" (Richard, 2000: 31) y y un "referente icónico" (Da Silva Catela, 2009: 337) de la misma lucha por la verdad y la justicia en el país rioplatense.

Las razones de esta relación residen, evidente y primeramente, en los elementos distintivos propios de la imagen fotográfica que desde fines del siglo XIX es considerada una "huella de lo real"”2. Lo novedoso, en el caso de la fotografía argentina a partir de los '90 del siglo pasado, es que adquiere una nueva relación con el terrorismo de estado: ya no 'sólo' un objeto de archivo para certificar una existencia y reivindicar justicia, el discurso fotográfico se convierte en testimonio construido ex post para reflexionar, política y estéticamente, sobre el saldo traumático de la violencia estatal.

La hipótesis de este breve ensayo es que aquel primer uso 'documental' de la imagen fotográfica haya construido una especie de archivo para los fotógrafos que han venido después, proporcionándoles paradigmas de representación (que definiremos ausencia, resto y objeto), ayudándolos, de alguna forma, a resolver el problema de la representación de un objeto considerado irrepresentable ${ }^{3}$. Sin entrar en detalles que excederían los alcances de este trabajo, me parece importante detenerme en un aspecto central de este debate sobre la (ir)representabilidad del exterminio. Si es cierto que lo estético no se desvincula nunca de lo ético - y lo es especialmente en este caso -, es cierto también que separar -

\footnotetext{
${ }^{1}$ Sobre este tema ver también: Langland (2005) y Fortuny (2012).

${ }^{2}$ En 1889, por ejemplo el British Journal of Photograhy proponía la creación de un amplio archivo fotográfico "que pudiese contener el más completo testimonio del estado actual del mundo" (British Journal of photography, 1889: 688 cit. en Newhall, 1998: 326).

${ }^{3}$ La cuestión de la representabilidad del exterminio surge en el campo de los estudios sobre el Holocausto con la violenta polémica entre Didi-Huberman (curador de la muestra donde se presentaban cuatro fotos rescatadas del campo de Auschwitz) y Claude Lanzmann (quien sostenía la irrepresentabilidad); cfr. Didi-Hubermann (2003) y Claude Lanzmann (1994); sobre el debate ver también Wajcman (2001) y Pagnoux (2001). Desde la filosofía son fundamentales, al respecto, los aportes de Giorgio Agamben (2000), de Jean-Luc Nancy (2006) y Jacques Rancière (2011).
} 
Edoardo Balleta. Ausencia, resto, objeto...

temporáneamente- estos dos campos podría ayudarnos a colocar la cuestión en el contexto apropiado. Como acertadamente señala Jaume Peris Blanes (2005:54 y sgg.), pensar una irrepresentabilidad total y extrema del horror supone un conjunto de contradicciones y consecuencias inesperadas y, a mi manera de ver, indeseables. En el plano sistémico de la representación histórica, esto implicaría aislar el 'evento’ Shoah de los otros 'eventos', no sólo cuantitativamente sino cualitativamente de la categoría misma de 'evento' desplazándolo - como bien advierte también Agamben (2000) con su crítica al concepto de Holocausto - al campo mítico del discurso religioso. Por otra parte, en el plano de la "expresión", supondría la falacia - bien intencionada, por supuesto - de no tomar en cuenta que, lo que se le atribuiría a la Shoah, como unicum en términos de irrepresentabilidad, habría que "extenderl[o] a la experiencia de la muerte, de la violencia o del goce y, en general, a todo aquello que supone un plus para el sujeto sobre la mera significación” (Peris Blanes, 2005: 57), es decir no tomar en cuenta que dicha irrepresentabilidad no sería un unicum sino la cifra constituyente de lo que buena parte del pensamiento contemporáneo considera la relación entre realidad y lenguaje. En ambos casos, para retomar un término empleado por Agamben, una “trivialización” de ese mismo evento.

La cuestión a plantearse no debería ser, por lo tanto, si es posible representar/testimoniar un evento traumático, sino cómo hacerlo y - en nuestro caso -, cómo hacerlo por medio de fotografías ${ }^{4}$. Ahora bien, situándonos en el campo de la fotografía, la respuesta a ese cómo resulta obvia - sacando una foto en el momento en que el evento x tiene lugar - pero, a la vez insatisfactoria ${ }^{5}$. Lo dicho, en efecto, nos lleva a reflexionar sobre un aspecto fundamental del acto fotográfico, de su configuración semiótica y, por ende, de estas reflexiones: la relación de la fotografía con el tiempo. El poder testimonial de la fotografía (el "ha sido" de Barthes) supone que en el acto de producción de la foto, el productor y el sujeto-objeto se encuentren presentes en un mismo espacio-tiempo, al contrario, por ejemplo, de lo que ocurre con el texto verbal que puede producirse después. La fotografía supone presencia y se produce en el presente, y por lo tanto, se podría inferir, no es posible fotografiar el pasado.

Esto nos lleva a repensar el interrogante de hace momentos: ¿cómo testimoniar hoy un evento traumático del pasado por medio de fotografías actuales? Es decir, cómo se puede usar un texto fotográfico de hoy para 'hablar’ del pasado? ¿Qué herramientas, qué retóricas habrá de poner en la mesa el fotógrafo? La dificultad objetiva que tienen que enfrentar este tipo de imágenes reside, en primer lugar, en su poder “documental”: pensando la foto como espejo de lo real, estamos delatando sus límites

\footnotetext{
${ }^{4}$ El “cómo" corresponde aquí a las “elecciones” de Rancière (2001: 96).

${ }^{5}$ Los casos que se conforman con esta modalidad de testimonio fotográfico son las conocidas fotos de Auschwitz (DidiHuberman), y, en ámbito argentino, las fotos que un ex-preso de la ESMA, Víctor Basterra, rescató y dio a conocer.
} 
Edoardo Balleta. Ausencia, resto, objeto...

(la fotografía es un médium de contacto, se da en la contemporaneidad entre productor y referente), lo cual aumenta su poder pero limita su campo de acción.

Lo anteriormente dicho se superpone, en la Argentina, a la peculiar dificultad conceptual de poder pensar la desaparición:

Frente al desaparecido en tanto esté como tal, es una incógnita el desaparecido. Si el hombre apareciera, bueno, tendría un tratamiento X. Y si la desaparición se convirtiera en certeza de su fallecimiento, tiene un tratamiento Z. Pero mientras sea desaparecido no puede tener ningún tratamiento especial, es una incógnita, es un desaparecido, no tiene entidad, no está. Ni muerto ni vivo, está desaparecido ${ }^{6}$. (J. Videla).

Si bien Videla nunca debe haberse preocupado demasiado por comprender las consecuencias éticas de la desaparición, lo que dicen sus palabras puede ayudarnos (aquí y en este momento) a penetrar el entramado de relaciones que estoy tratando de establecer entre la fotografía, la imagen, el presente, el pasado, la presencia, la ausencia. El desaparecido, dice implícitamente el militar genocida, no tiene identidad ("no puede tener...") porque está falto de aparecer, no tiene ni visibilidad ni presencia. ¿Qué puede la fotografía frente a esto?

Frente a esta dificultad conceptual de poder pensar la desaparición, frente a una "política de la desaparición”, como agudamente observa Natalia Fortuny, los fotógrafos se encontraron ante la necesidad de construir una "estética de la desaparición” (Fortuny, 2010: s.p.) 7.

\section{El archivo}

Antes de abordar los ensayos fotográficos, es importante concentrarnos un momento sobre su prehistoria, es decir sobre el conjunto de imágenes fotográficas que, en distintas formas y épocas, han entrado al espacio colectivo. Estas pueden dividirse en tres grupos:

\section{Fotos personales}

2. Fotos institucionales tomadas al interior de los campos durante la dictadura

3. Fotos institucionales tomadas después de la caída de la dictadura (fotos de la CONADEP) ${ }^{8}$.

\footnotetext{
${ }^{6}$ La declaración, reportada por el diario Clarín el 14 de diciembre de 1979, está disponible en youtube.

${ }^{7}$ La idea de “estética de la desaparición” es retomada de Jean-Louis Déotte, “El arte en la época de la desaparición” in Nelly Richard, Políticas y estéticas de la memoria, Cuarto Propio, Santiago, 2000.

${ }^{8}$ Sobre las fotos personales y las fotos tomadas en los centros clandestinos de detención ver: García y Longoni (2013); sobre las fotos contenidas en el Nunca Más, Crenzel (2009).
} 
Edoardo Balleta. Ausencia, resto, objeto...

Como primer acercamiento al tema, será importante tomar en cuenta algunas variables tales como el tipo de uso (práctico, simbólico) y, entre otras, el contexto de fruición (privado, público).

En relación con el primer grupo, las foto-carnets circularon inicialmente como prueba de existencia y objeto práctico para encontrar al familiar o al ser querido (en comisarias, en las calles etc.); a la vez, esas mismas fotos tuvieron, en el ámbito privado del hogar, una colocación espacial definida y la función de hacer posible una ‘elaboración del duelo’ (Da Silva Catela, 2009). Desplazándonos de lo privado a lo público, esas mismas fotos adquieren una función política en las marchas y sufren un proceso de ‘colectivización’ (un militante no necesariamente lleva consigo la pancarta de $s u$ desaparecido).

Del segundo grupo forman parte las fotos tomadas por militares o presos dentro de los campos de detención; al presente las únicas fotos que se conocen son las que Víctor Basterra (un ex-preso) logró sacar de la ESMA a riesgo de su propia vida. Pueden catalogarse en tres grupos: a) fotos de militares (para documentos falsos), b) fotos ambientales (como las sacadas por Basterra u otros presos para testimoniar), c) fotos de desaparecidos de frente y de perfil (Longoni y García, 2013) ${ }^{9}$.

Al tercer grupo pertenecen las fotos producidas por la CONADEP. En este caso el 'archivo' es producido después de la dictadura, y su valor documental de 'prueba' se sustenta sobre todo en el contexto iconográfico y su relación con el texto verbal: los referentes que se muestran pueden descodificarse sólo haciendo referencia a un conjunto de vivencias y conocimientos que quedan afuera de la imagen. Se trata, en suma, de huellas, restos.

Dentro de este cuadro general, cabe considerar otro elemento que, si bien no forma parte de "lo fotográfico", ha seguramente dejado huellas fundamentales en el imaginario visual del post-dictadura: el Siluetazo ${ }^{10}$. Aunque no voy a entrar en los detalles de la realización del proyecto, sí es importante mostrar sus resultados (fig. 1). El proyecto pone al desnudo los límites de figurabilidad propios de la dimensión de la desaparición, su núcleo paradójico: "el que está dibujado" - escriben los autores en la presentación del proyecto - "no está” (Aguerreberry, Flores, Kexel, 2008: 64). Es en la presencia - y presentación - de la ausencia que el Siluetazo encuentra, a mi manera de ver, la clave para contrarrestar la aporía sobre la que se funda la desaparición y crear un paradigma de representabilidad (o figurabilidad) liminar.

\footnotetext{
${ }^{9}$ Una de estas imágenes es la foto de Fernando Brodsky recuperada por el hermano Marcelo en Buena Memoria (1996).

${ }^{10}$ Un análisis pormenorizado del evento y una rica selección de documentos puede encontrarse en Longoni, Bruzzone y Lebenglik (2008).
} 


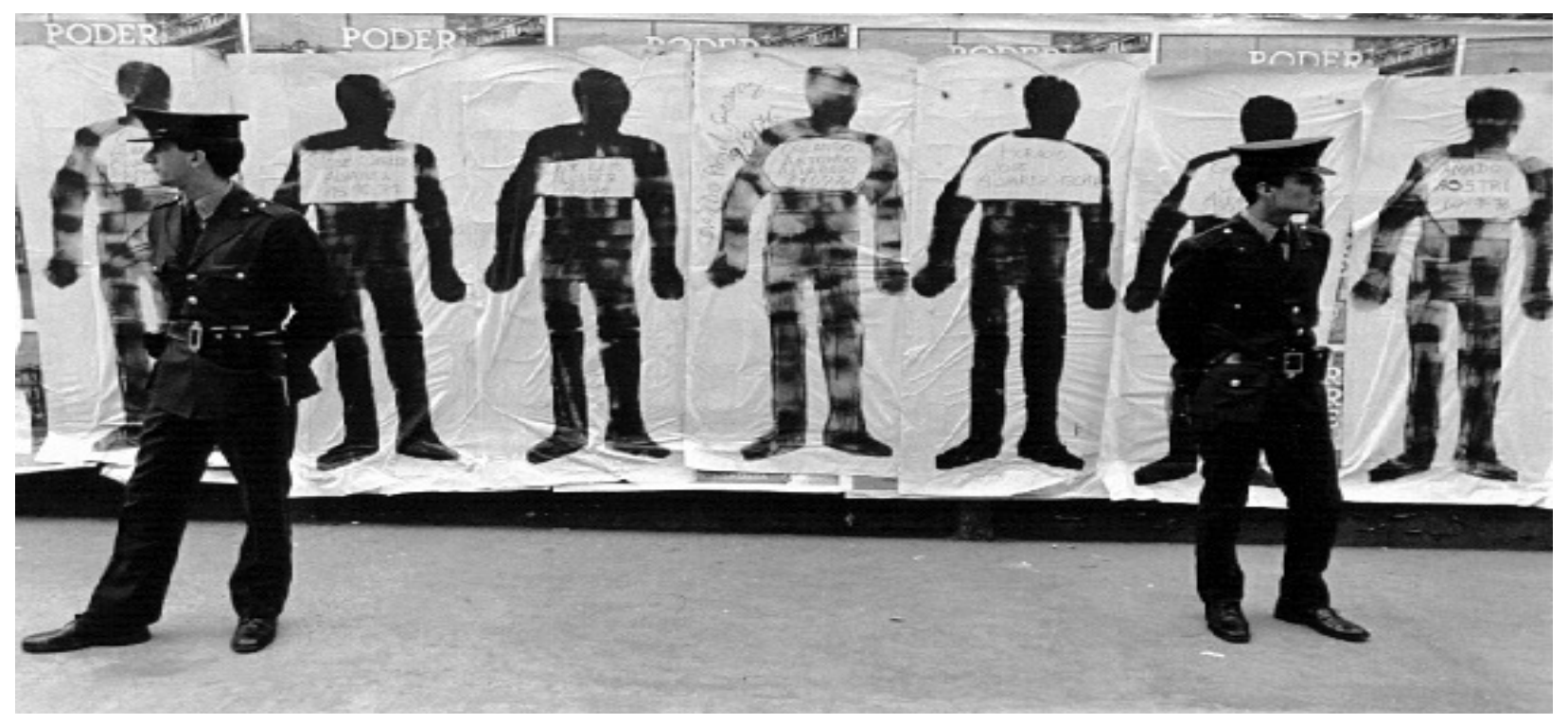

Figura 1: Siluetazo (fotografia Eduardo Gil)

\section{Tres paradigmas}

Recuerdo las palabras de Natalia Fortuny: los fotógrafos tratan de "construir una estética de la desaparición” frente a una "política de la desaparición”. Mi propuesta es tratar de empezar a definir un poco mejor los rasgos generales de dicha “estética de la desaparición”. Para ello me parece que trabajar, primero, sobre el archivo, significa conocer los elementos icónicos que los fotógrafos, que producen obras a partir de los '80, han podido tener a mano y que, consciente o inconscientemente, han posiblemente influenciado su producción. Dentro del corpus al que acabamos de referirnos, he podido encontrar tres modos de representación iconográfica de la desaparición que podrían identificarse como tres diferentes paradigmas: la ausencia (el Siluetazo), el resto (las fotos del Nunca Más; fig. 2) y el objeto (la foto-carnet) ${ }^{11}$.

\footnotetext{
${ }^{11}$ No hay que considerar, evidentemente, este intento de categorización como compartimentos estancos, sino como tres posibilidades expresivas que los artistas pueden usar en distintos modos; cuando hablo de objeto considero la imagen fotográfica no como un texto cuyo sentido surge de un proceso de descodificación sino como res que funciona, más allá del campo icónico, por contigüidad metonímica con el sujeto ausente; esto porque, más allá de su uso práctico y de su socialización, la foto adquiere entre los familiares valor en si; tanto las fotos familiares como las fotos, por ej., de V. Basterra, se vuelven ya no sólo huellas sino signos en si, objetos sustitutos de una ausencia. Como veremos, sobre todo para la generación de los hijos, la fotografía ya no es sólo "imagen (bella, artística, conmovedora etc.) sino también un "dispositivo paradigmático de representación de la ausencia” (Fortuny, 2011: s.p.)
} 


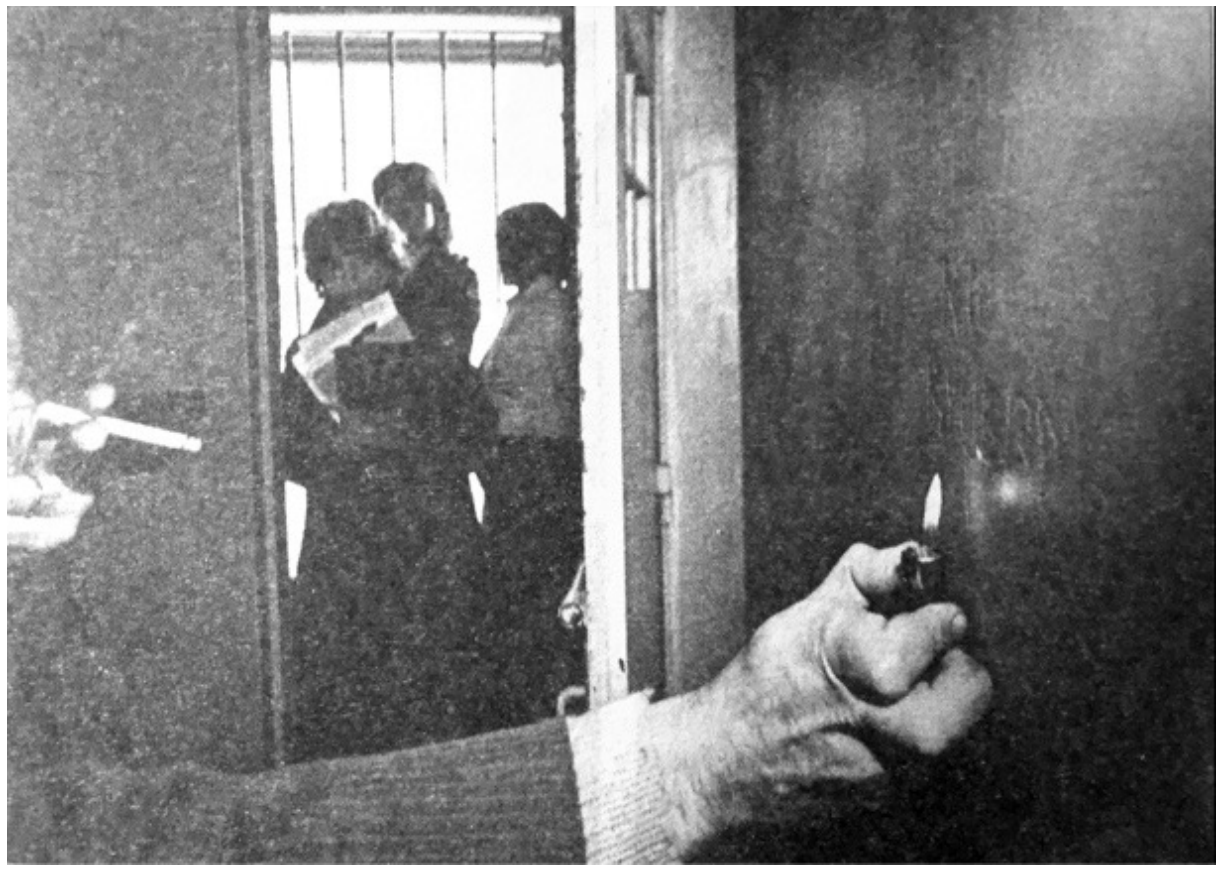

Figura 2: Centro Clandestino de Detención "Pozo de Banfield" en el Nunca Más

\section{La ausencia: ¿Dónde están? (RES, 1989)}

La serie ¿Dónde están? (1989) del fotógrafo cordobés Res es probablemente el primer ensayo fotográfico en que se trabaja el tema de la desaparición. Lo que se ve en las fotos - casi manieristas - son imágenes nocturnas de un paisaje urbano donde aparecen fragmentos de un cuerpo (el del propio fotógrafo, que tiene entre las manos un frasco cuyo contenido, difícil de descifrar, es el feto de un tapir). El proceso de descodificación funciona a partir del para-texto (el título) ya que las imágenes no muestran bajo ninguna forma una relación explícita con el tema. La foto se construye, por lo tanto, casi negando su indexicalidad: el ensayo comienza por una pregunta a la que el observador no puede contestar, puesto que lo que las fotos transportan es una ausencia.

Es precisamente la imagen del tapir que, a partir del proceso desencadenado por el título del ensayo, puede establecer una conexión con las fotos-carnet (el referente ausente); sólo gracias a elementos extra-icónicos el observador puede activar un proceso de descodificación que le permitirá crear una red de significación ${ }^{12}$.

\footnotetext{
12 Para un análisis de esta serie de Res, cfr. Fortuny 2011 b.
} 
La foto del feto de tapir establece una conexión con las foto-carnets de los desaparecidos y el escenario metropolitano indica el redescubrimiento de la ciudad como lugar vivible y transitable (vs. la ciudad sitiada por la dictadura) pero, a la vez, muestra que este espacio no ha vuelto todavía a ser realmente el ámbito de lo colectivo (la ciudad está vacía). El tiempo de exposición alto contribuye, finalmente, a crear, como advierte el proprio Res ${ }^{13}$, una serie de imágenes donde el sujeto humano aparece como una presencia fantasmática que se desplaza no sólo en el espacio, sino también en el tiempo: como sugiere González, las imágenes de Res exhiben un carácter estratigráfico ${ }^{14}$ que permite la superposición de eventos, intentando resolver así, de manera claramente paradójica y sufrida, el problema de fotografiar al pasado. La ausencia, en esta serie de Res, representa un paradigma porque es un punto de partida, un escollo que se supera elaborando una estética de la desaparición.

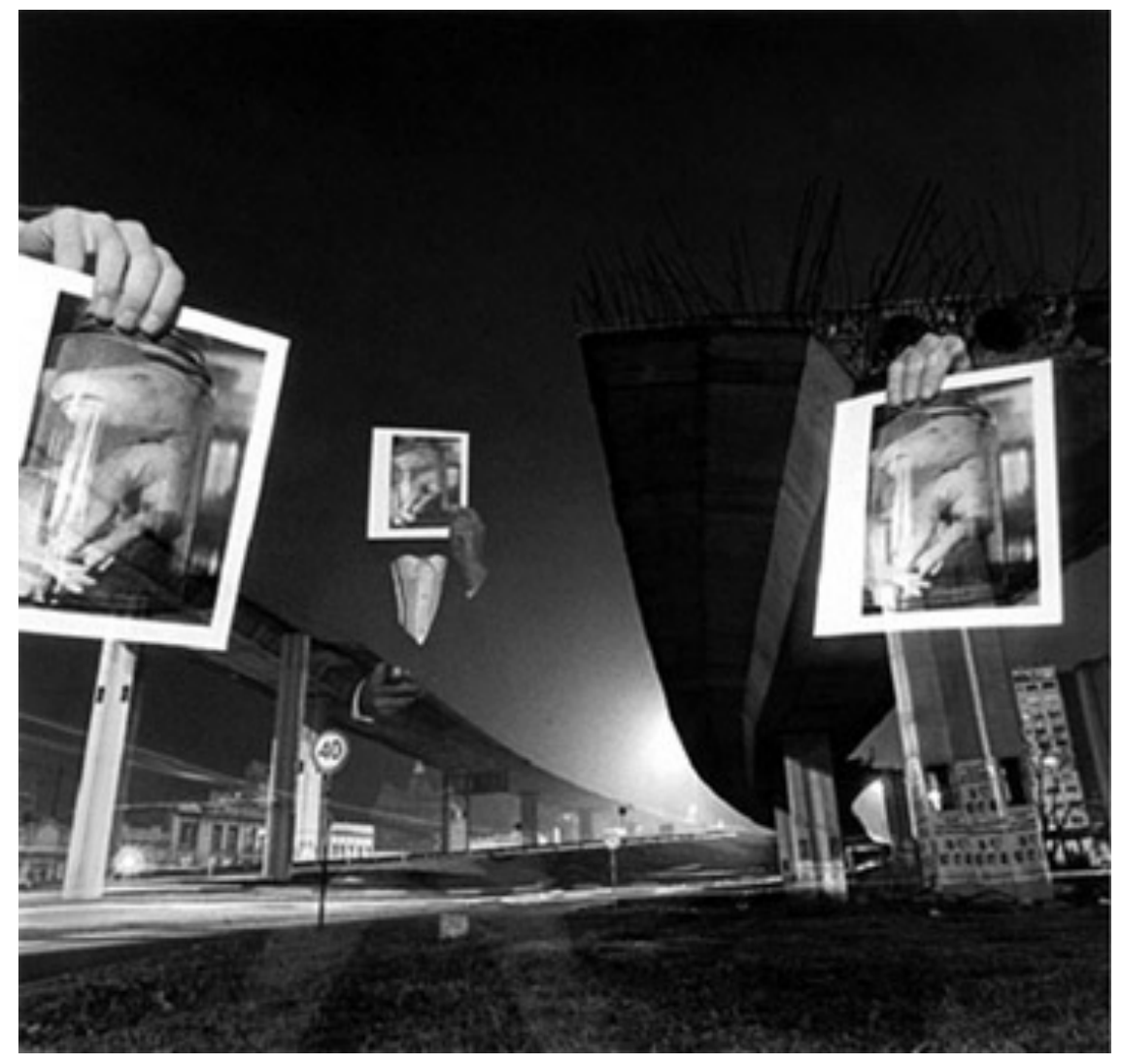

Figura 3: ¿Donde están? (RES, 1989)

\footnotetext{
13 "Las exposiciones fueron lo suficientemente largas como para darme tiempo a aparecer como un fantasma en las imágenes" in http://www.resh.com.ar/imanes/texto.htm

14 Valeria González, "Los palimpsestos de la memoria” en La verdad inútil: RES fotografías 1983-2003, Ediciones Museo Caraffa Córdoba, 2003, cit. en Fortuny, 2011b.
} 


\section{Resto: Treintamil}

Si bien el caso de Treintamil (1996) de Fernando Gutiérrez tiene elementos en común con el de Res ${ }^{15}$, es oportuno abordar el ensayo también desde otra perspectiva: el discurso de Res, metafórico, llama a la ausencia, el de Gutiérrez, metonímico, trabaja sobre la presencia. De hecho, la imagen de Gutiérrez no funciona ya como alegoría (como ocurre en Res, donde el observador tiene que encontrar la llave y descodificar - tapir/desaparecido) - sino que se funda en una relación de continuidad. Tanto en el primer ensayo como en los siguientes (Secuela 2001-2004; Cosas al río 2008-10) lo que la imagen exhibe no son cuerpos ni simulacros, sino restos: objetos que podemos observar aún en el presente y que forman parte de la memoria visual colectiva: los aviones, el río, los centros clandestinos, el Ford Falcon etc.

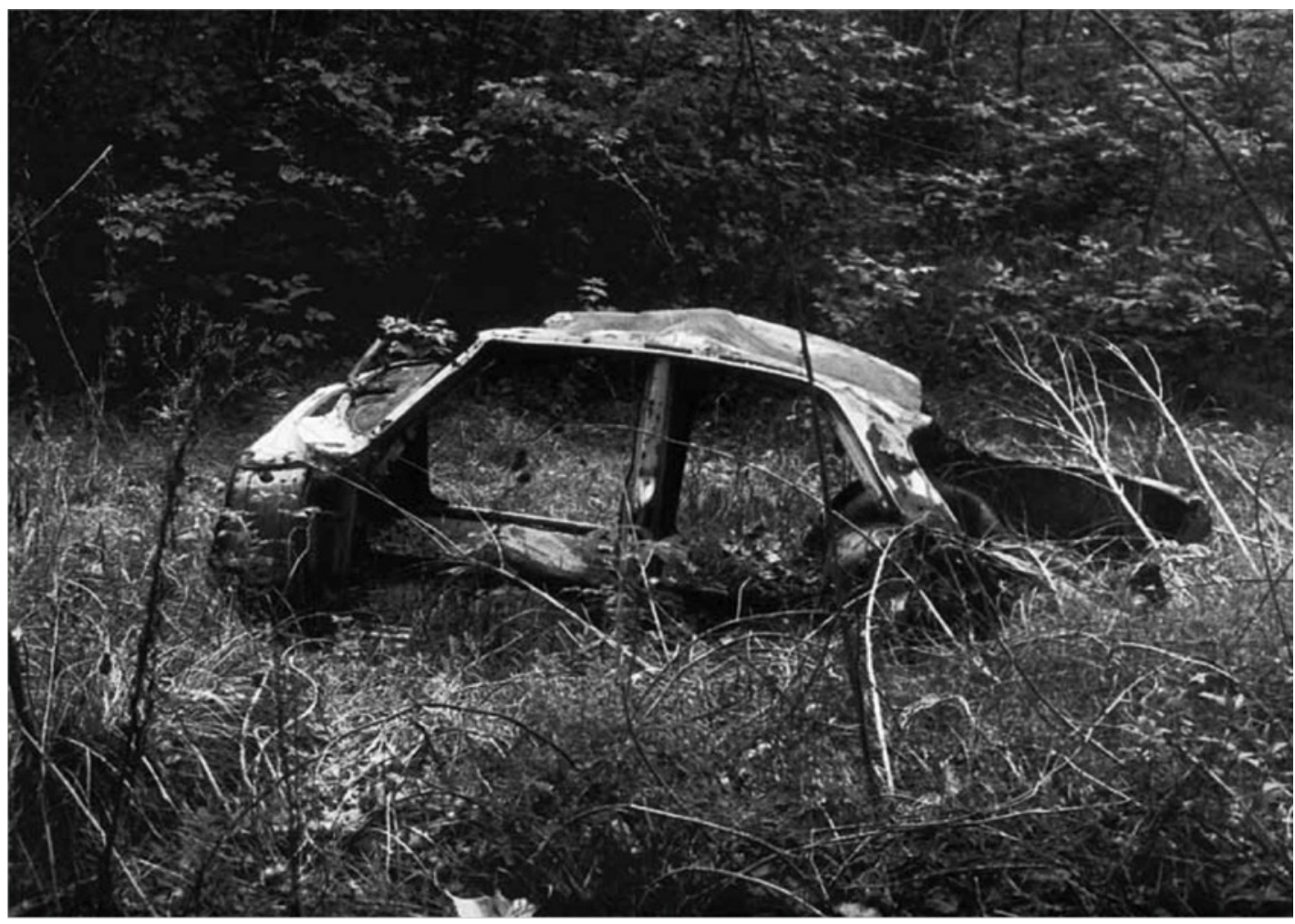

Figura 4: Treintamil (F. Gutiérrez, 1996)

\footnotetext{
${ }^{15}$ Fortuny (2012) observa: "las fotos de Gutiérrez se alinean con las de Res para presentar un mundo de restos..."; es cierto que ambos fotógrafos exhiben "restos", pero creo que en el caso de Res son restos en sentido de "desechos" que no remiten directamente al tema de las fotos, mientras que en Gutiérrez, considero los "restos" como "huellas" que reenvían directamente al contexto de la dictadura.
} 
Otra novedad si comparamos Treintamil con el ensayo de RES, es que en el de Gutiérrez, en su conjunto, empieza a vislumbrarse cierta narratividad: a pesar de que el fotógrafo, en este caso, no tenga una relación directa y familiar con el tema, decide construir su 'narración' a partir de una experiencia traumática de su propia infancia. En el primer texto, que aparece al lado de la imagen del auto quemada, leemos que, siendo chico, junto a dos amigos, Gutiérrez estaba jugando en ese mismo coche, cuando oyó llegar una patrulla; los chicos trataron de fugarse pero, cambiaron sus planes al oír unos disparos. Fueron alcanzados por los hombres de la patrulla, quienes comenzaron a amenazarlos hasta que los dejaron irse. Este texto breve permite, junto al título, que se inicie el proceso de descodificación, lo cual no habría sido posible acudiendo simplemente a la imagen. El observador puede ahora abordar el texto fotográfico: la carcasa del auto (fig. 4), en este contexto, entra en una constelación que evoca el Ford falcon. Las imágenes siguientes reconstruyen la escena de un secuestro, hasta mostrar unas sombras humanas, un rostro, un edificio, unas rejas con alambres, un grupo de camiones del ejercito (fig. 6).

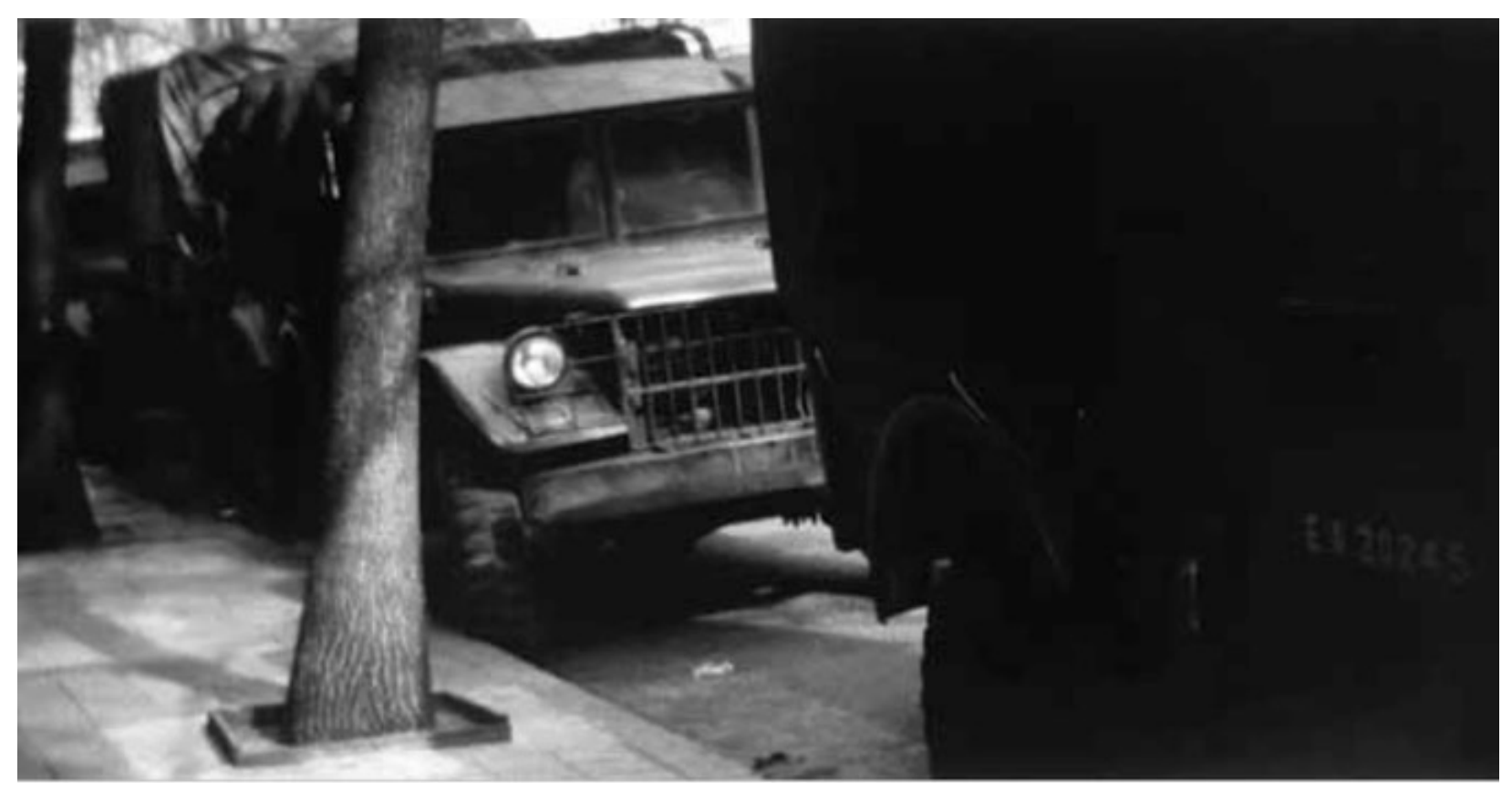

Figura 6: Treintamil (Gutiérrez, 1996)

Al lado de la foto en la que se ve una carretera desierta (fig. 5), encontramos otro texto que hace que el lector/observador comprenda que está por comenzar una nueva 'secuencia’:

Primero mataremos a todos los subversivos, luego a sus colaboradores, luego a sus simpatizantes, luego a quienes permanezcan indiferentes, y por último, mataremos a los indecisos (Declaración del Gral. Ibérico Saint Jean, Gobernador de la provincia de Buenos Aires, 1977) 
En todo el país existieron durante la última dictadura militar más de 600 Centros Clandestinos de Detención que constituyeron el material indispensable de la política de desaparición de personas. (Gutiérrez, 1997) ${ }^{16}$.

Con la imagen siguiente (fig. 7), se introduce visualmente lo que acabamos de leer. Siguen tres imágenes de lugares desolados y un tercer intervento para-textual:

Una vez en el avión la dosis de anestesia era reforzada. Finalmente eran arrojados desnudos a las aguas del Río de la Plata desde los aviones en vuelo.

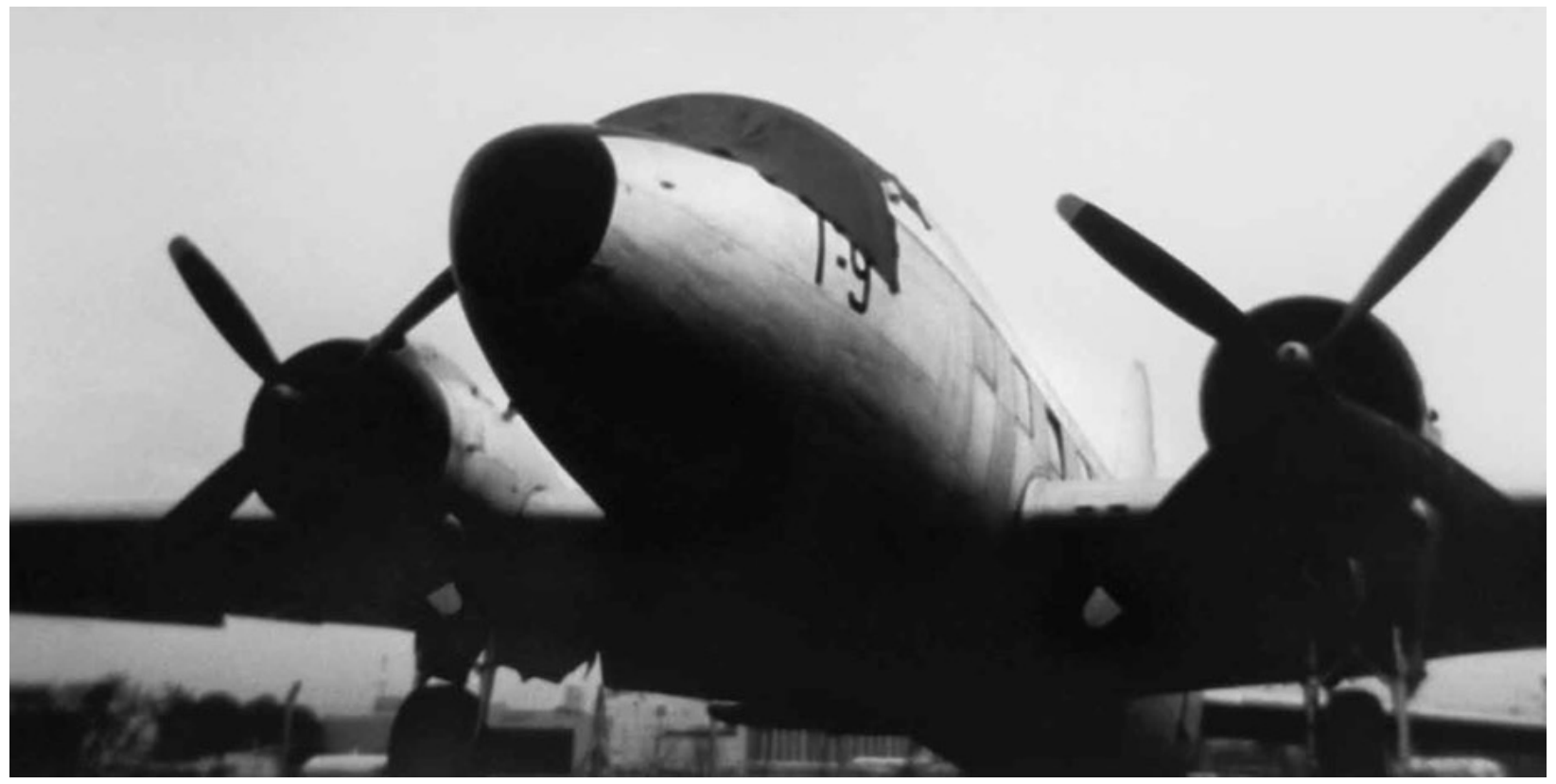

Figura7: Treintamil (Gutiérrez, 1996)

Aquí se sugiere la escena de un avión de la muerte, condensando, en una misma imagen, tanto una alusión a la víctima (el avión tiene vendas) como al 'victimario'.

La última imagen (fig. 8), de tamaño menor, se ocupa de reubicar la narración en el presente: tres pares de zapatos, pero solo dos pies.

\footnotetext{
${ }^{16}$ Una reimpresión del ensayo puede encontrarse en el catálogo: Fernando Gutiérrez, Treintamil. Secuela. Cosas al Río, Centro Cultural de la Memoria Haroldo Conti, Buenos Aires, 2014, s.p., y está disponible online: http:// conti.derhuman.jus.gov.ar/2014/05/f-fernando-gutierrez.pdf.
} 


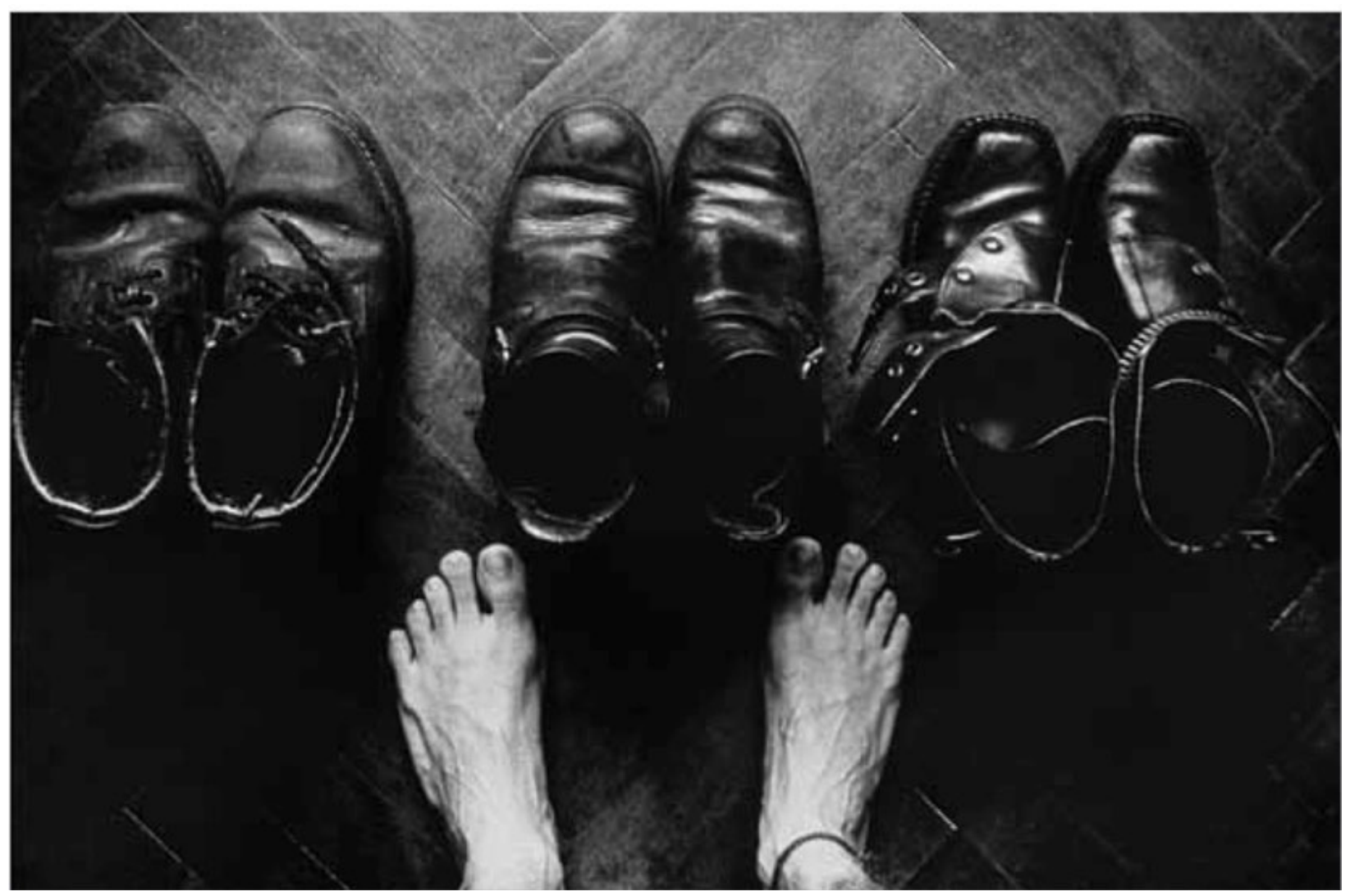

Figura 8: Treintamil (Gutiérrez, 1996)

Pese a las diferencias evidentes con respecto al discurso de Res, en esta serie de Gutiérrez los paradigmas sugeridos empiezan a estratificarse: Gutiérrez construye su narración por imágenes a partir del resto (auto, camionetas, aviones...) pero a la hora de volver al presente, acude a la ausencia: los tres pares de zapatos (un claro reenvío a los zapatos amontonados en los campos de concentración nazi), son el límite de lo visible, la huella de una ausencia. 


\section{El objeto: Buena Memoria (Marcelo Brodsky, 1996)}

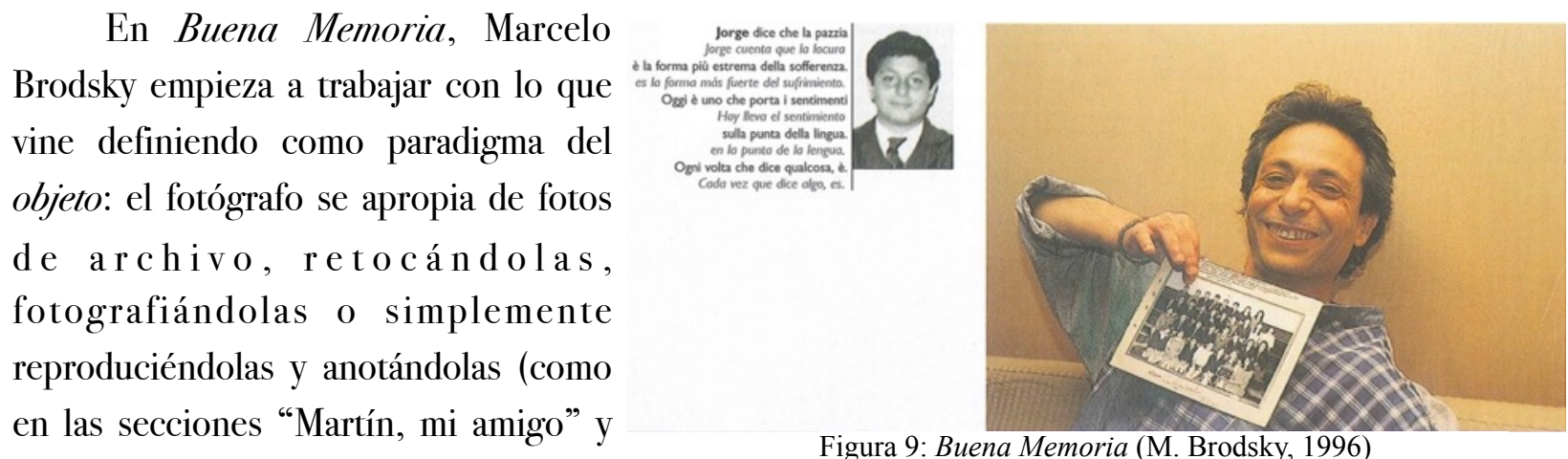
"Nando, mi hermano").

El proyecto se compone, efectivamente, de cuatro partes ("Ier año VI división, 1967. Los compañeros", "Puente de la memoria" "Martín, mi amigo", "Nando, mi hermano"). La primera sección, la más conocida se construye en torno a dos elementos: la foto (retocada) de su división en el primer año del secundario (fig. 9) y una serie de fotos de ex-compañeros en el presente que muestran la foto de grupo y un objeto que los representa hoy. El juego entre pasado y presente se establece a partir de la interferencia entre palabra e imagen: donde la imagen cuenta el pasado de un grupo de adolescentes que asistían al colegio público más importante de la Argentina, la palabra condensa en pocas líneas el tiempo

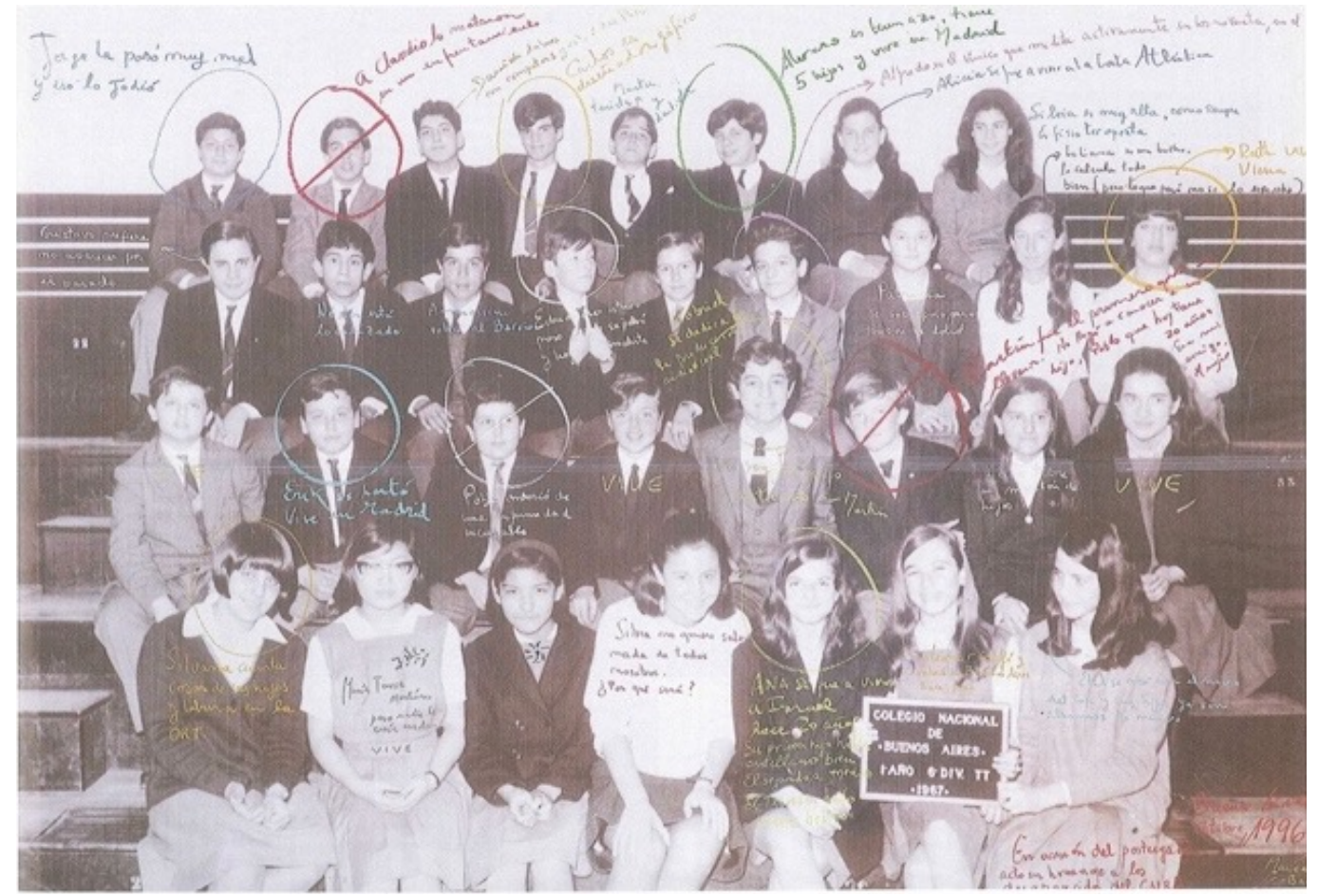

Figura 10: Buena Memoria (M. Brodsky, 1996) 
transcurrido: uno vive en el exterior, otro tuvo hijos, otro tiene un buen trabajo. Todo parece llevar hacia la narración 'clásica' y apaciguadora de una reunión de excompañeros. Pero otras palabras empujan al observador hacia una situación claramente más traumática: otro se exilió, otro estuvo en cana, Jorge "se la pasó muy mal y eso lo

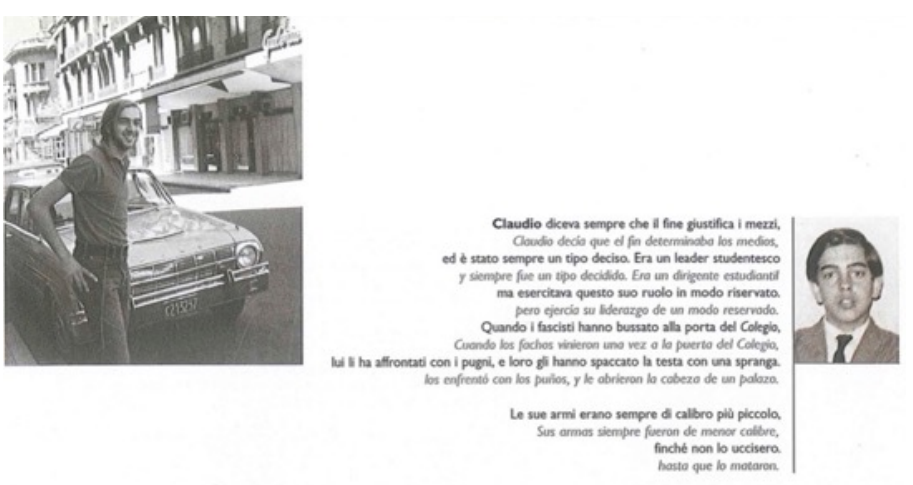
jodió”, mientras Martín, el mejor amigo de Brodsky, que fue el primero en caer preso, "nunca conoció a su hijo".

Visualmente M. Brodsky construye, a partir del discurso "ex-compañeros", un universo a la vez cotidiano y perturbador. Por un lado, la continuidad estilística, ritmada por la co-presencia de fotografías del pasado y del hoy (fig. 10), se quiebra cuando los sujetos son Claudio y Martín, muerto el primero, desaparecido el segundo; aquí la

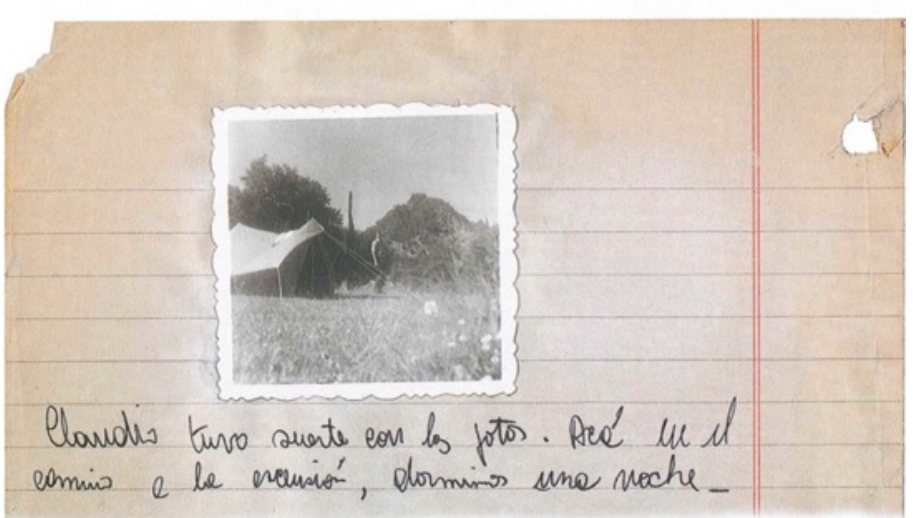

Figura 11: Buena Memoria (M. Brodsky, 1996) imagen actual tiene que dejar espacio a las fotos del pasado (fig. 11) que rompen la unidad visual del conjunto. Secundariamente, esta co-presencia (el mismo ser humano retratado en distintas épocas de su vida) obliga al observador a concentrarse sobre el paso del tiempo. Y en esta operación, retomada y desarrollada - como veremos - de forma extremadamente original por Gustavo Germano en 2007, se puede penetrar el sentido profundo de la obra: ofrecer un amoroso y tierno homenaje a quienes ya no están y, a la vez, exhibir la irreparabilidad, la distancia, el sobresalto que la experiencia de la memoria puede llegar a suscitar: muertos que serán siempre jóvenes.

\section{La foto: a partir del 2000}

Con el nuevo milenio y por distintas razones, este tipo de producción fotográfica memorial experimenta un verdadero boom. Si bien en la ya consistente bibliografía crítica no hay intentos de explicación de este auge, creo que se podría arriesgar la hipótesis de una confluencia de múltiples factores históricos, políticos y sociales que en su conjunto podría arrojar luz sobre el fenómeno. En 


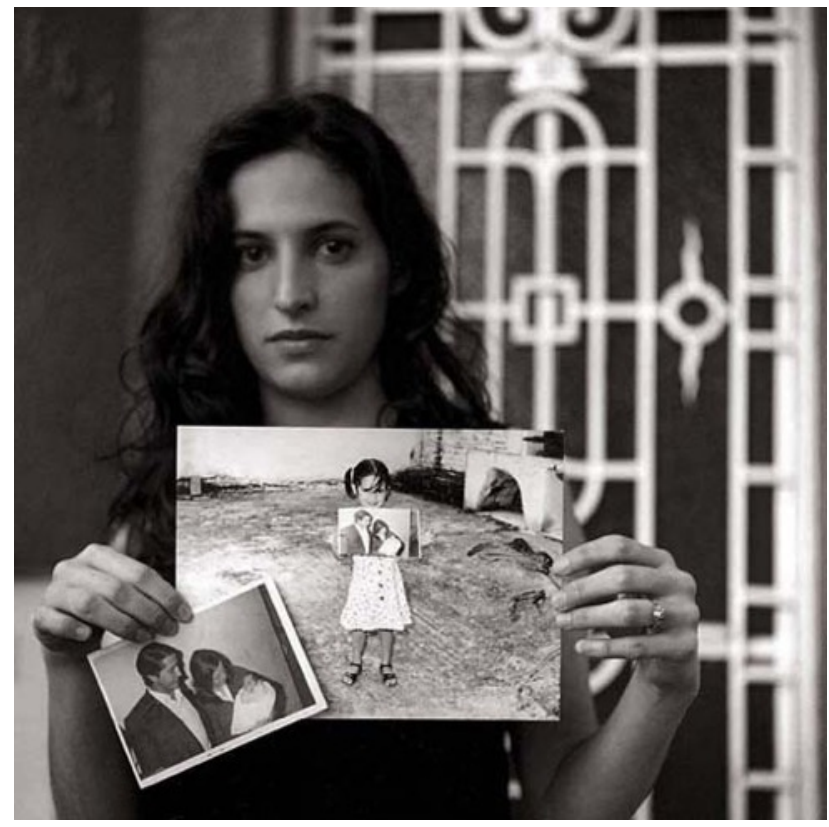

Figura 12: Los Hijos. Tucumán Veinte años después (J. Pantoja, 1997-2001) primer lugar (factores históricos) hay que considerar el paso del tiempo como un lapso suficiente para empezar a metabolizar el trauma, también a partir de eventos de alto impacto público como los aniversarios y su valor simbólico; secundariamente (factores políticos) el Estado Nacional y los gobiernos provinciales, ya a partir de finales de los '90 comienzan a promover leyes e iniciativas para fomentar el surgimiento de una memoria institucional y compartida ${ }^{17}$; finalmente, con el nuevo milenio, tanto en las artes visuales como en literatura, empieza a salir a la escena una nueva generación nacida entre finales de los ' 60 y de los '70 que reivindica su derecho a hablar desde lugares, evidentemente, distintos $\mathrm{y}$, en esta generación, se encuentran hijos y familiares de desaparecidos que, como advierte agudamente Ana

Longoni conocieron "a su padre o su madre a través de esas pocas y ajadas fotos atesoradas y escondidas" y por eso, como advierte Longoni no sería casual que muchos entre ellos se expresen, artísticamente, por medio de imágenes (Longoni en Fortuny 2014: 8). Esta reflexión nos ayuda a identificar los rasgos comunes que destacan estos nuevos ensayos donde prima, en conjunto, el paradigma del objeto. Aunque no falten obras que apelan al resto (Gutiérrez, Secuela 2001; Inés Ulanovsky, ESMA, 2010; M. Brodsky, Los condenados de la tierra, 2000) o a la ausencia (Clara Rosson, Tarde o Temprano, 2006), en la gran mayoría de los casos la foto en tanto objeto tiene un papel protagónico en la construcción de las imágenes. La foto de época entra directamente a formar parte de la composición de la foto actual, es decir que la imagen final resulta ser una foto que contiene otra foto. En el caso de Julio Pantoja (Los Hijos. Tucumán Veinte años después, 1997-2001, fig. 12) la integración de la foto en la foto es una libre decisión de algunos de los hijos retratados mientras que otros aparecen sin la foto. Fotos tuyas de Inés Ulanovsky, aunque es mucho más complejo estructuralmente, trabaja los objetos fotográficos de la misma

\footnotetext{
${ }^{17}$ Se pueden mencionar, a modo de ejemplo: la ley n. 46 (21 de julio de 1998, Ciudad Autonoma de Buenos Aires) que instituye el Parque de la Memoria en el área costanera, la ley nacional 25.633 (1 de agosto de 2002; institución del 24 de marzo como "Día Nacional de la Memoria por la Verdad y la Justicia") y la ley 1.412 (5 de agosto de 2004) que sanciona la creación del "Espacio para la Memoria y para la Promoción y Defensa de los Derechos Humanos" en los predios de la ESMA; para un debate sobre la destinación cultural del predio de la ESMA puede leerse: Vezzetti (2004) y Brodsky (2005).
} 
manera: en la serie aparecen valijas y cajas llena de fotos, fotos apoyadas sobre muebles y colgando de las paredes y fotos de familiares interactuando con las fotos de época. (figg. 13-14). En Arqueologías de la Ausencia (2001) de Lucila Quieto, en cambio, la foto de los padres es proyectada en la pared y sobre el cuerpo mismo del hijo creando, en la confusión de planes, espacios y tiempos, la ilusión de un diálogo, de una relación que, a priori, se muestra como imposible.

Bettini, por otra parte, "juega" con las fotos de su tío y su abuelo que, para entrar en la nueva imagen, sufren un proceso de re-elaboración más evidente tanto en la composición (la foto antigua
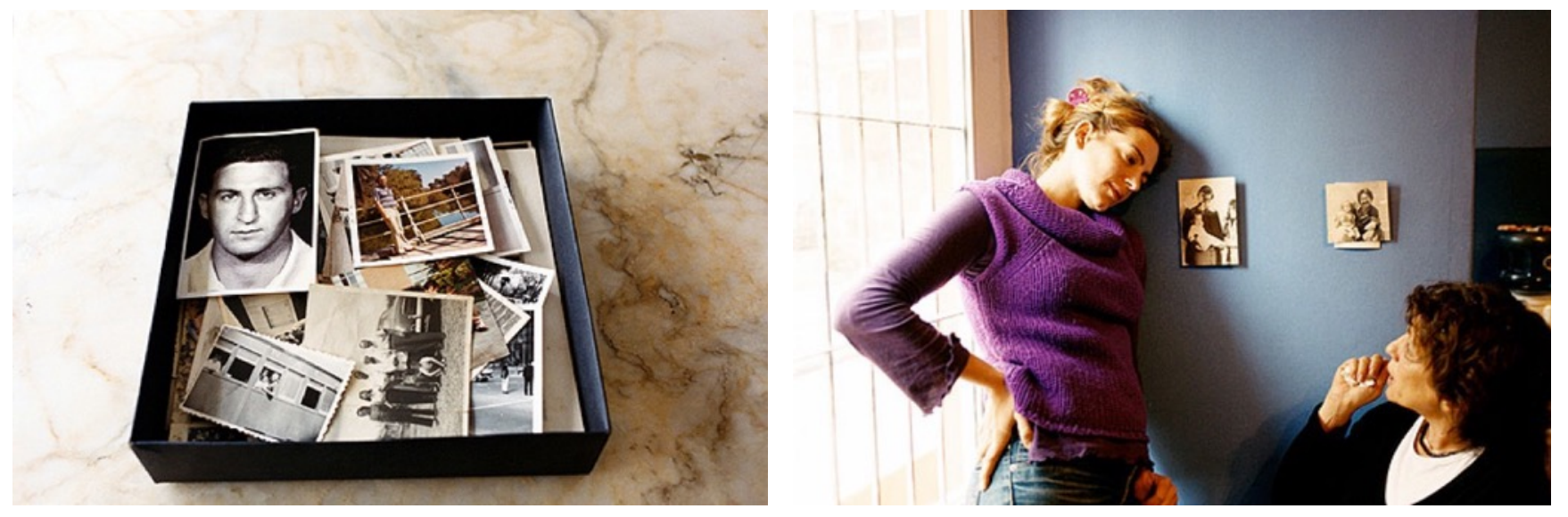

Figura 13-14: Fotos tuyas (I. Ulanovsky, 2006)

'disimula' ser una foto) como en la actitud que el sujeto vivo entabla con el retratado (fig. 14). En otro grupo de proyectos (los de Guadalupe Gaona, Camilo Pérez del Cerro, María Soledad Nívoli) el objeto fotográfico ya no entra en la nueva imagen en su materialidad sino que funciona como disparador, medium a partir del cual el hijo-productor de la imagen puede establecer una relación en ausencia ya no con el cuerpo del padre a través de su simulacro (como en Quieto) sino con sus vivencias, sus formas de ver el mundo. En Elviaje de papá (Camilo Pérez del Cerro, 2005), por ejemplo, el autor trabaja con el fotomontaje interviniendo las fotos que su padre -Hernán Pérez del Cerro, asesinado el 9 de junio de 1977 por la dictadura militar- había tomado durante un viaje por el mundo hacia la mitad de los años '60: entre fotos originales y no retocadas, sacadas por el padre, aparecen otras en que asoma el hijo, entrando en la imagen gracias al fotomontaje, y logrando así compartir la vida del padre, el mismo 
espacio-tiempo, su mirada sobre el mundo ${ }^{18}$. Más radicales, en esa misma línea, los trabajos de Guadalupe Gaona (Pozo de aire) y María Soledad Nívoli (Cómo miran tus ojos) que llegan casi a eliminar su propia presencia para dejar paso a la intimidad del recuerdo o a la mirada del padre ${ }^{19}$. En el caso de Pozo de aire, un libro híbrido entre la poesía y la fotografía, todo empieza con una foto, la única, donde la fotógrafa-poeta de niña se encuentra a solas con el padre durante unas vacaciones en el Sur. A partir de este punto - literalmente el origen -, los textos y las imágenes (que mezclan fotos del álbum de familia con fotos sacadas por la propia Gaona) se ocupan de recomponer la memoria de su niñez en un movimiento regresivo para "encontrar y reconstruir algo de esa imagen del bote [el retrato con el padre], algo del momento feliz en esa huidiza refulgencia del pasado" (Fortuny, 2014: 98). El padre, visualmente un hápax, casi no aparece, porque de alguna forma se encuentra - lo imaginamos - detrás de la cámara, sacando las fotos del álbum de familia que estamos mirando, que se conectarán con otras fotos - las de Gaona - en un diálogo fuera del tiempo. En esa misma línea se mueve también el proyecto Cómo miran tus ojos de María Soledad Nívoli (2007). En este caso lo que se ve son fotos de distintas partes del país que aparecen en dos 'versiones': primero en las imágenes tomadas por el padre en los años ’60, después en las sacadas por Nívoli y su colaborador D’Assoro ${ }^{20}$. El título de la muestra aclara su

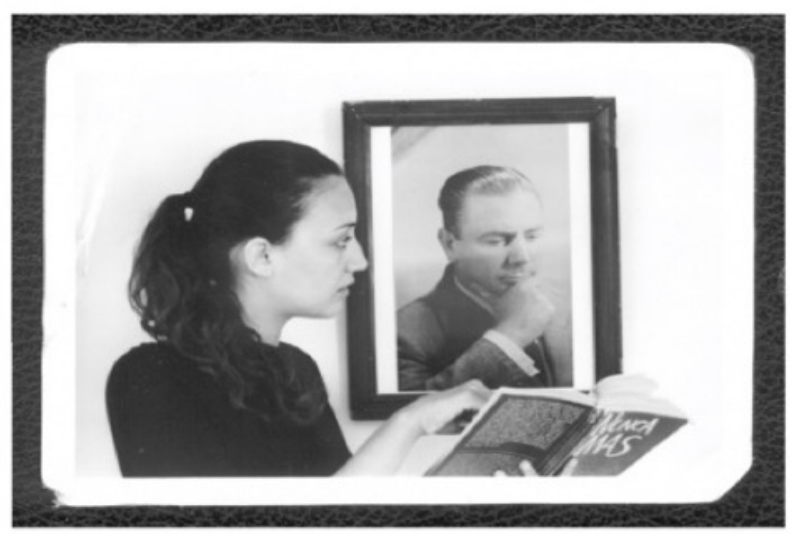

Figura 14: Recuerdos inventados (G. Bettini, 2002-03)

\footnotetext{
${ }^{18}$ Entre el ensayo de Camilo Pérez del Cerro y los de L. Quieto y G. Bettini hay seguramente afinidades a nivel estructural (los tres trabajan la relación entre foto de época de los padres o familiares y la identidad del fotógrafo-sujeto-hijo del presente), pero lo que me interesa destacar acá es cómo las distintas elecciones formales implican un 'producto' final visualmente distinto y, por ende, una recepción distinta por parte del observador.

${ }^{19}$ Sigo en este punto el análisis de Fortuny (2014: 96-101).

${ }^{20}$ El proyecto de Nívoli es el único imaginado por un no fotógrafo y realizado gracias a la colaboración con un profesional.
} 
Edoardo Balleta. Ausencia, resto, objeto...

sentido: la presencia del padre ya no es buscada en una imagen-simulacro, sino en su forma de mirar. El resultado invita al observador a un juego de comparación entre ambas fotos, un "crossword iconográfico de la memoria" (Blejmar y Fortuny, 2011: s.p.), pero lo que cuenta es sobre todo el gesto: cómo miran tus ojos - así, con tilde - es un interrogante cuya respuesta aparente, las fotos, son - en realidad - nada más que un intento de aproximación al padre, donde no cuenta el resultado sino el proceso que ha llevado a ello.

\section{Ausencias de Gustavo Germano}

A lo largo de este ensayo he intentado trazar un pequeño recorrido por lo que podríamos denominar, fotografía testimonial de la post-dictadura, intentando mostrar sus orígenes visuales y evidenciando como, a partir de ello, pueden definirse tres espacios - paradigmas - de representación visual de la memoria. Lo que me interesa ahora, en esta última parte del trabajo, es detenerme un poco más en detalle sobre un último ensayo fotográfico en el que confluirían estos tres paradigmas, un proyecto que, si bien superficialmente muy simple, me parece uno de los más densos y acabados tanto visual como conceptualmente.

Ausencias se compone de 14 dípticos fotográficos de gran tamaño: la primera imagen es una foto original de los '60/'70 y la segunda una 'copia' de la primera, sacada por Gustavo Germano en 2006: se retratan los mismos sujetos, en el mismo lugar, pero se impone la ausencia de los que fueron muertos o desaparecidos por la última dictadura militar.

Ausencias, en las intenciones de Germano, iba a formar parte de una trilogía sobre las formas de represión del poder de las que ya se han desarrollado las dos primeras partes: Ausencias, sobre la desaparición/muerte, Distancias, sobre el exilio y la tercera parte (sobre la cárcel) que, finalmente, no fue posible realizar ${ }^{21}$. La exposición, debido a su voluntad militante de poder exponerse en cualquier condición, es muy versátil: puede montarse sólo con los 14 dípticos y unas pequeñas leyendas en que se da el nombre de los retratados. En el catálogo de la muestra, en cambio, aparecen más informaciones. Cada serie se compone de cuatro hojas: en las primeras dos figuran las fotos, en la tercera los nombres de los retratados junto a una escueta descripción periodística sobre quién era el desaparecido y las circunstancias de su desaparición/muerte y -finalmente- en la cuarta, unas pequeñas prosas poéticas en que se cruzan algunas sugestiones sobre el paisaje entrerriano con vivencias y relatos de los familiares y amigos que participaron en el proyecto.

\footnotetext{
${ }^{21}$ Las informaciones que consigno aquí son el resultado de una charla con el fotógrafo que tuve la ocasión de entrevistar el 25 de abril de 2013 después del estreno de la muestra Ausencias en Rovereto (Trento, Italia); antes de someter la versión final del presente trabajo mantuve otro intercambio con G. Germano, que me permitió actualizar algunas datos.
} 
Otro elemento fundamental es el cuidado extremo de los aspectos gráficos (a cargo de Vanina de Monte) del montaje: la preeminencia del blanco ‘total' y la creación de un 'logo' ad hoc que, borrando el ‘palito’ de la letra “i” de Ausencias retoma, impresionísticamente, el concepto de ausencia.

Desde el punto de vista documental la elección de las fotos originales fue realizada gracias a la colaboración con el Registro Único de la Verdad de Entre Ríos, la agrupación HIJOS PARANÁ y la asociación AFADER (Asociación de Familiares y Amigos de Detenidos-Desaparecidos) de la misma provincia de Entre Ríos.

Después de este momento previo de investigación, Gustavo Germano hizo una primera selección de las fotos y de las historias a 'contar', tomando en cuenta dos variables: por un lado, desde el punto de vista de la construcción del relato, el material en su conjunto debía representar un abanico que fuera lo más amplio posible para mostrar la variedad del universo social, cultural y político de las personas que fueron víctimas de la dictadura (grupos de militancia, profesión, clase social, edad, etc.). Por otro lado, las fotos tenían que reflejar esta misma 'variedad' desde lo visual, incluyendo imágenes sacadas en interiores, exteriores, primeros planos, fotos sacadas de lejos etc.

El paso siguiente fue el de proponer el proyecto a los familiares y amigos y colaborar con ellos: la idea general que Gustavo Germano les propuso fue que las fotos que él iba a tomar los retratara, en lo posible, en la misma posición y actitud, si bien a la hora de enfrentarse concretamente con cada uno de los retratos, el mismo fotógrafo no haya optado, en algunos casos por la foto que más se asemejaba, entre las varias pruebas, al original ${ }^{22}$.

Después de esta necesaria, y muy básica, descripción del proyecto, lo que me interesa ver aquí son las modalidades de construcción tanto de las fotos individuales como del conjunto. Por lo tanto, la pregunta, a la que trataré de responder no será "Qué significa" - lo cual, por otra parte, es obvio - sino "cómo" se llega a transmitir este significado que convoca una participación emotiva del observador. En la bibliografía crítica sobre Ausencias, ya otros han trabajado sobre su dimensión testimonial desde el punto de vista de la reconstrucción de una memoria colectiva ${ }^{23}$. Lo que, en cambio, me interesa ver aquí es el "cómo", porque a través de ese "cómo", me parece, se puede llegar a individuar algunos elementos claves que pertenecen a la dimensión ética del valor del testimonio y de su representación estética. Por otra parte el proyecto, al desplazar el punto de vista desde el sujeto desaparecido hacia las personas involucradas emocionalmente con su desaparición, permitiría pensar la cuestión no ya desde la

\footnotetext{
${ }^{22}$ Un caso destacado de esta falta de correspondencia es la foto de Claudio Marcelo Fink y de su madre Clara Atelman de Fink: la madre en la foto reciente mira fijo en cámara en vez de mirar hacia la silla vacía; según me contó el propio Germano, inicialmente las fotos habían sido sacadas en esta pose, pero el resultado no funcionaba; para una lectura de este par fotográfico de Ausencia ver Chababo, Rubén. "Clara Atelman De Fink." Revista Memória em Rede 2.4 (2011).

${ }^{23}$ Ver, por ej., Fortuny (2008) y Fam (2012).
} 
perspectiva de la construcción de un saber judicial (de denuncia), sino que la misma 'denuncia' pasaría a mostrar el tamaño, las dimensiones y las repercusiones sociales de la represión y la desaparición forzada: las víctimas - aunque la palabra tenga algo que no me gusta - no son 30.000, nos están diciendo las fotos, sino todos los hombres, mujeres, niños y niñas del entorno afectivo de cada uno de estos 30.000 .
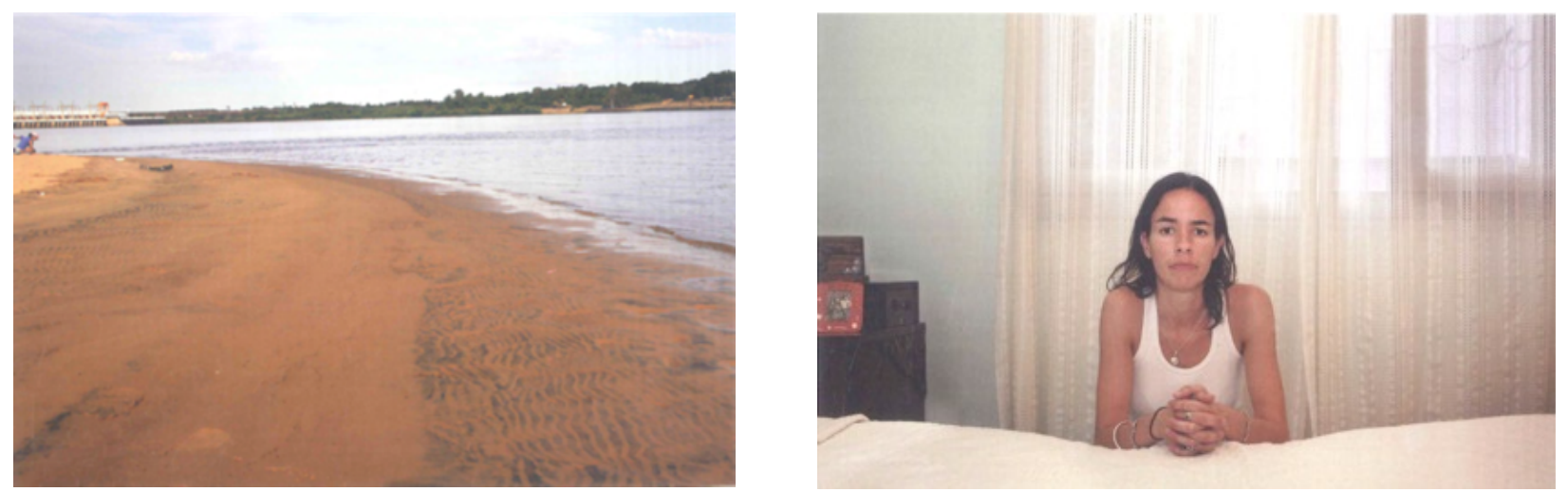

Figura 15-16: G. Germano, Ausencias

Desde el punto de vista de la construcción de la 'narración' cabe destacar dos elementos. Por un lado, como vimos, la selección de las fotos correspondería a una voluntad de presentar un abanico lo más amplio posible de historias; por otro lado, el proyecto se abre con una ausencia total (fig. 15) y se cierra, en cambio, con una presencia (fig. 16); es más, ambos grupos de fotos pertenecen a un mismo núcleo familiar: en la primera foto del primer díptico se ven dos jóvenes solos tendidos en la playa (Orlando René Mendez y Leticia Margarita Oliva) y en el último, los mismos jóvenes llevando en sus brazos un bebé que después de 30 años ha crecido convirtiéndose en la mujer retratada en la foto que cierra el proyecto. Ya con este primer elemento se puede observar como el proyecto articula una serie de oposiciones estructurales que se suman y conectan, como veremos, de manera inesperada. A la oposición primaria (presencia/ausencia) se suma ahora la oposición "muerte/vida” y sus subcontrarios (no muerte/no vida) que apuntan a la condición suspensa del 'desaparecido' y de los familiares en duelo. Otro elemento sobre el cual cabe reflexionar atañe al grado de mímesis: desde el punto de vista técnico y 'estilístico', las fotos de Germano no tratan de asemejarse a los originales: no copian los 'errores' hechos por los fotógrafos aficionados (enfoque, abertura etc.) ni los límites técnicos de las cámaras antiguas; igualmente, en la post-producción, las fotos no fueron retocadas para 'anticuarlas' (aunque en la primera fase del proyecto se haya considerado esta posibilidad). Lo único que se hace es retomar el mismo contexto, las mismas personas sobrevivientes y, en la mayoría de los casos, la misma pose de los sujetos. Este me parece un elemento clave por distintas razones. Estructuralmente las imágenes de 2006, al no 
optar por una mimesis técnica total, otorgan unidad visual y estética al conjunto (lo cual sería imposible con las otras elecciones). Secundariamente, esto permite resaltar la distancia (temporal) entre los originales y las 'copias', logrando un efecto de desfase, de paradoja. Por último, demuestra una voluntad de ‘invisibilización’ (aparente) del fotógrafo y, a mi manera de ver, hace que, por un lado, el conjunto transmita cierta 'frialdad' y rehuya la hiper-emotividad y, por el otro, que el observador no se pierda en medio de demasiados artilugios. En cambio, lo que la yuxtaposición de las dos imágenes estimula es un ejercicio antes intelectual y luego emotivo: la mirada se concentra en la búsqueda de semejanzas y diferencias en lo que se ve (presencia/ausencia). Aunque haya presencias humanas e inanimadas (objetos) que se repiten en las dos fotos, sobre el conjunto de lo visible se impone la ausencia. Otro elemento clave del proyecto es la relación opositiva de las temporalidades (presente/pasado). Desde este punto de vista hay que reflexionar, en primera instancia, sobre la relación entre dimensión temporal y fotografía: Walter Benjamin, Susan Sontag y Roland Barthes otorgan a esta relación un sentido estructural. Gustavo Germano capta esta dimensión fundacional del retrato y la subraya en el paratexto del catálogo por medio de una cita tomada de John Berger:

El verdadero contenido de una fotografía es invisible, porque no se deriva de una relación con la forma, sino con el tiempo [...] Los objetos registrados en cualquier fotografía (desde el más impactante al más común) transmiten aproximadamente el mismo peso, la misma convicción. Lo que varía es la intensidad con la que se nos hace conscientes de los polos de ausencia y presencia [...] Al mismo tiempo que se registra lo que se ha visto, una foto, por su propia naturaleza, se refiere siempre a lo que no se ve. Lo que muestra invoca lo que no muestra, revela lo ausente igual que lo que está presente en ella.

(J. Berger "Entender una fotografía” en Sobre las propiedades del retrato fotográfico").

Presente y pasado, por lo tanto, constituyen otra de las oposiciones clave sobre las cuales se construyen las imágenes y el proyecto en su conjunto. Y esta, a su vez, trae consigo otras: presente y pasado, articulados en su dimensión humana, remiten a juventud/vejez con todas las implicaciones que esta cuarta oposición trae a colación: bello/feo, esperanzas/recuerdos etc. etc.

He aquí un primer elemento a tomar en cuenta: en cada fotografía y en el conjunto se imponen al observador, quizás de forma inconsciente, algunas oposiciones que, analíticamente, podemos articular en una cadena: presencia/ausencia, vida/muerte (y no vida/no muerte), presente/pasado, juventud/ vejez, belleza/fealdad, esperanza/recuerdos etc. Las fotos de Germano funcionan a partir de una serie de ambigüedades e incoherencias derivadas de la paradoja que sugiere, ya implícitamente, el título del proyecto: imágenes que retratan la ausencia. Surge de esta paradoja una pregunta: ¿quién o quiénes es/ son el/los protagonista/s de las imágenes? El desaparecido (que sólo aparece en una de las dos fotos) o los familiares/amigos que aparecen en ambas y que ya no son los mismos? Evidentemente la pregunta no tiene respuesta o, si preferimos, las respuestas son ambas e inescindibles. Además, esta paradoja 
primaria (retratar lo invisible) que las fotos transmiten impone a la mirada del observador una cadena de oposiciones cuyas articulaciones trastocan la lógica asociativa ‘común'. Todos los elementos de la cadena que estamos acostumbrados a asociar con lo positivo y lo negativo (presencia-vida-presente-juventudbelleza-esperanzas; ausencia-muerte-pasado-vejez-fealdad-recuerdos) se encuentran desplazados, asociados de forma distinta: es el desaparecido (ausente o muerto; negatividad) quien, al quedar ‘congelado' en una imagen del pasado, será siempre joven, bello, lleno de esperanzas y de futuro (positividad), lo cual hace cortocircuitar nuestra experiencia del mundo. Por otra parte, los que están vivos (positividad en el presente) son los que van acercándose a la vejez: sus cuerpos llevan las marcas del paso del tiempo (negatividad) y por consiguiente se acercan a la muerte: las canas, las gorduras, las calvas, las arrugas, las miradas, el bastón, son huellas del paso del tiempo que simbólicamente remite al fin de la vida pero que implícitamente supone, también, la 'normalidad' de una existencia que, en cambio, está negada a los sujetos que siempre serán bellos, jóvenes y llenos de futuro, pero a quienes les fue vedada esta posibilidad.

Por último me gustaría, después de este análisis descontextualizado, volver a colocar la obra de Germano en su espacio y considerarla como parte del conjunto de imágenes que, en los últimos treinta años, han representado la dictadura y la post-dictadura. En este marco, un continuum que va desde la foto familiar del desaparecido hacia la colectividad, el proyecto de Germano añade, en línea con lo ensayado por Marcelo Brodsky, un eslabón más: desde la ausencia, se concentra en las vivencias y las experiencias de los familiares y de los amigos de los que no están. Aunque los protagonistas sean los 'ausentes', la estructura de cada díptico hace que el observador se concentre en quienes permanecen visibles. De esta forma, el punto de vista y la atención se desplazan del desaparecido a sus familiares y amigos, destacando como las consecuencias de la desaparición forzada no se limitan a lo individual sino que envisten lo familiar, el entorno social (amigos) e intergeneracional (hijos) dejando, en suma, una huella profunda en la sociedad toda. Los restos en el ensayo de Germano ya no son los objetos que recuerdan, por contigüidad, los íconos de la dictadura como los Ford Falcon o el Club Atlético de Gutiérrez, sino - en oposición - seres humanos, los amigos y los familiares de quienes fallecieron. En esta variación puede leerse, a contraluz, un cambio de perspectiva que, no exento de contradicciones y dolor, ya no apela al discurso sobre la muerte, sino que piensa en la vida, casi un nuevo inicio, en términos arendtianos. El objeto-foto sigue estando presente pero sale del cuadro, ya no se trata de una foto de una foto, ya no es un simulacro, un amuleto, un objeto-sustituto, sino un médium que permite proyectarse hacia el futuro. 
Edoardo Balleta. Ausencia, resto, objeto...

\section{Bibliografía}

Agamben, Giorgio (2000). Lo que queda de Auschwitz: El Archivo y el Testigo (Homo Sacer III). Valencia: Pre-textos.

Aguerreberry Rodolfo, Flores Julio y Kexel Guillermo (2008). "Propuesta presentada a las Madres de Plaza de Mayo (1983)”. Longoni Ana, Bruzzone Gustavo y Kexel Guillermo.

Blejmar, Jordana y Fortuny Natalia. "Miradas de otro. El regreso a lo perdido en dos ejercicios fotográficos de memoria”. Revista Estudios 25 (2011).

Brodsky, Marcelo (2005). Memoria en construcción: el debate sobre la ESMA. Buenos Aires: La Marca Editora.

Chababo, Rubén (2011). “Clara Atelman De Fink.”. Revista Memória em Rede 2.4.

Crenzel, Emilio (2009). "Las fotografías del Nunca Más: verdad y prueba jurídica de las desapariciones” en Feld, Claudia y Stites Mor, Jessica (comp.). El pasado que miramos. Memoria e Imagen ante la historia reciente. Buenso Aires: Paidós: 281-313.

Da Silva Catela, Ludmila (2009). "Lo invisible revelado. El uso de fotografías como (re)presentación de la desaparición de personas en la Argentina”. Feld Claudia y Stites Mor Jessica (comp.). El pasado que miramos. Buenos Aires: Paidós: 337-361.

Didi-Huberman, Georges (2003). Images malgré tout. Paris: Les éditions de Minuit.

Fortuny Natalia (2014). Memorias Fotográficas. Imagen y dictadura en la fotografía argentina contemporánea. Buenos Aires: La luminosa.

Fam, Beatriz. "Ausência da presença, presença da ausência: vestígios que não se pode apagar.” En Imagem E Memoria. (Ed. Elisa Amorim y Elcio Cornelsen). Sao Paulo: n.p., 2012.

Fortuny, Natalia. "La foto que le falta al álbum. Memoria familiar, desaparición y reconstrucción fotográfica”. Memoria de Las Jornada Nacionales de Investigadores en Comunicación 12 (2008).

Fortuny, Natalia. "Máquinas del tiempo: artefactos y dispositivos de muerte en la fotografía argentina posdictatorial”. Question 1, no. 20 (2011).

Fortuny, Natalia. “¿Dónde están? La espacialidad fotográfica, el cuerpo y la memoria en una serie temprana de Res”. Question 1, no. 23 (2011b).

Fortuny, Natalia. "Memoria fotográfica. Restos de la desaparición, imágenes familiares y huellas del horror en la fotografía argentina posdictatorial”. Amerika. Mémoires, identités, territoires 2 (2012): s.p.

García, Luis Ignacio y Longoni, Ana (2013). "Imágenes invisibles: acerca de las fotos de desaparecidos” 
Blejmar, Jordana, Fortuny Natalia y García Luis Ignacio Instantáneas de la memoria. Fotografía y Dictadura en Argentina y América Latina. Buenos Aires: Libraria.

Germano, Gustavo. Ausencias/Assenze (edizione bilingue) (2008). Barcellona, Torino: Museo diffuso della resistenza, della deportazione, della guerra, dei diritti e della libertà.

Gutiérrez, Fernando. Treintamil (1997) Buenos Aires: La marca.

Langland, Victoria (2005). "Fotografía y memoria”. Jelin, Elizabeth y Longoni, Ana (comp.). Escrituras, imágenes y escenarios ante la represión. Buenos Aires: Siglo XXI: 87-91.

Lanzmann, Claude. “Holocauste, la representation impossible”. Le monde, 3 marzo de 1994.

Longoni, Ana, Bruzzone Gustavo y Lebenglik Fabián (2008). El Siluetazo. Buenos Aires: Adriana Hidalgo Editora.

Nancy, Jean-Luc (2006). La representación prohibida. Buenos Aires-Madrid: Amorrortu.

Newhall, Beaumont (1998). Storia della fotografia. Torino: Einaudi.

Pagnoux Elisabeth. "Reporter photographe à Auschwitz". Les temps modernes 56/ 613 (2001) .

Peris Blanes, Jaume (2005. La imposible voz. Memoria y representación de los campos de concentración en Chile. Santiago de Chile: Cuarto Propio.

Rancière, Jacques (2011). El destino de las imágenes. Buenos Aires: Prometeo Libros.

Richard, Nelly (2000). "Memoria, fotografía y desaparición: drama y tramas".Punto de Vista 68: 29-33.

Vezzetti Hugo, "Políticas de la memoria: el museo en la Esma”. Punto de Vista 79 (2004): 3-8.

Wajcman, Georges. “De la croyance photographique”. Les temps modernes 56/613 (2001). 